\title{
A Panacea for the Nation : Berkeley's Tar-water and Irish Domestic Development
}

\section{Scott Breuninger}

\section{Q OpenEdition \\ 12 Journals}

\section{Electronic version}

URL: http://journals.openedition.org/etudesirlandaises/2618

DOI: 10.4000/etudesirlandaises. 2618

ISSN: 2259-8863

\section{Publisher}

Presses universitaires de Rennes

\section{Printed version}

Date of publication: 30 September 2009

Number of pages: $29-41$

ISBN: 978-2-7535-0982-5

ISSN: 0183-973X

\section{Electronic reference}

Scott Breuninger, "A Panacea for the Nation : Berkeley's Tar-water and Irish Domestic Development ", Études irlandaises [Online], 34.2 | 2009, Online since 30 June 2011, connection on 04 May 2019. URL: http://journals.openedition.org/etudesirlandaises/2618; DOI : 10.4000/etudesirlandaises.2618

This text was automatically generated on 4 May 2019.

(c) Presses universitaires de Rennes 


\title{
A Panacea for the Nation : Berkeley's Tar-water and Irish Domestic Development
}

\author{
Scott Breuninger
}

1 Following his return to Ireland after his aborted plan to settle a missionary college in Bermuda, George Berkeley was appointed Bishop of Cloyne (1734) and soon confronted the harsh conditions facing his charges. His first response to these problems was a series of economic tracts, The Querist (1735-1737), that provided patriotic guidance for improving the health of the Irish economy vis-à-vis England. While these texts were read widely, their influence upon the general well-being of his flock was negligible. This was especially true after poor harvests and endemic poverty conspired to lower the standard of living throughout the island, a situation acerbated by the spread of epidemics during the early 1740s. Faced with these challenges, Berkeley published his controversial, and oft-overlooked, Siris (1744).

2 For philosophers concerned with Berkeley's legacy Siris is rarely mentioned as anything other than a curiosity; yet during his own life, his call for the use of tar-water was extraordinarily popular and helped cement his reputation as "the good bishop". By promoting an affordable solution to pressing national problems, Berkeley provided a practical avenue for Irish patriots to improve the welfare of their countrymen. This paper will first locate Berkeley's Siris within its Irish context, noting how the nation was suffering through a period of great socio-economic stress. After outlining the impetus for this work and sketching its practical dimension, I will then survey the popular responses to it from contemporary defenders of medical orthodoxy. Finally, I will end with some thoughts concerning the place of Siris in Berkeley's larger project, contending that rather than being seen as a point of departure, or "a new enthusiasm", the metaphysical underpinnings contained therein harkened back to his earliest popular writings in The Guardian'. In particular, Berkeley's evocation of the 'great chain of being' in Siris and the very structure of this text, drew upon notions of human sociability that suggest Berkeley 
held an inclusive view of humanity that crossed sectarian lines, holding out hope for the improvement of all inhabitants of Ireland.

\section{Historical Context(s) : Berkeley's Career and Cloyne}

Despite Berkeley's reputation today as a key philosopher of idealism, the texts that formed the basis for this legacy were written while he was still a struggling research fellow at Trinity College ${ }^{3}$. These works were certainly influential, but his reputation as "the good bishop" and Pope's attribution to him of "ev'ry virtue under heav'n" stemmed from a lifetime of practical plans aimed at improving the lives of others ${ }^{4}$. After being appointed Bishop of Cloyne, Berkeley was acutely engaged with Irish economic issues. Supported by Thomas Prior and Samuel Madden, Berkeley's analyses were published as The Querist and illustrate his attitudes towards the sectarian and class differences that plagued Irish society. These proscriptions for the economic well being of his native land were closely linked to Berkeley's espousal of an Irish patriotism grounded in a practical recognition of the challenges facing Ireland as a whole. While this mature position contained elements of religious prejudice, these were tempered by a greater concern for creating a self-sufficient state able to weather the storms of social upheaval.

By the late 1730s, Berkeley had established himself in Cloyne and by all accounts was devoted to the well being of his flock. Cloyne was an isolated and impoverished area, but Berkeley implemented a number of plans aimed at improving local conditions. Drawing upon the ideas of fellow members of the Dublin Society, Berkeley organized a spinning school, built a workhouse for vagrants, and experimented with the cultivation of hemp and flax ${ }^{5}$. In addition to encouraging economic development, Berkeley created a center of learning and culture, eventually retaining an "eminent Italian Master of Musick in his house ${ }^{6}$ ". While these innovations pointed toward growing prosperity, nature soon intervened and wrought havoc in Berkeley's plans.

The winter of 1739-1740 was exceptionally harsh and caused great devastation throughout Ireland. The author of The Distressed State of Ireland Considered (1740) observed that that "uncommon Height of Markets through the Summer, the Scarcity of Bread (that in some Places come near to a Famine) and the Poverty of the greater part of Buyers, are Hardships that have been very general though the Kingdom this Year?". Seeking to help relieve the plight of the poor, during the spring frost Berkeley donated $£ 20$ every Monday to the underprivileged of Cloyne and in a show of solidarity with his neighbors abstained from using precious flour to powder his wig until after the fall harvest ${ }^{8}$. Nonetheless, these moderate efforts were for naught and by the end of the summer Ireland faced near famine conditions that recalled those of the late 1720s. Contemporary reports described the "dearth of all sorts of Provision, attended by a severe and almost general Sickness, that by all accounts [has] nearly depopulated some parts of the Country". During the summer of 1740 an outbreak of smallpox hit Cloyne and by winter an epidemic of dysentery, in Berkeley's words the "bloody flux", had added further misery to the countryside ${ }^{10}$. By the following spring, Berkeley wrote that "the distresses of the sick and poor are endless", leading him to lament that the "nation probably will not recover this loss in a century ${ }^{11}$ ". Surveying this wreckage, the author of The Groans of Ireland (1741) described the nation as "the most miserable Scene of universal distress, that I have ever read of in History ${ }^{12}$ ". Faced with these awful conditions, Berkeley felt as though he had no 
option but to aid in whatever manner he could, an urge acerbated by the paucity of medical care available in the region.

During the early 1740s, Ireland suffered from a dearth of doctors, especially outside of Dublin. Medical care was primarily a matter of private enterprise and public benevolence, which in rural areas such as Cloyne meant that the poor were reliant upon the generosity of the local gentry and religious establishment ${ }^{13}$. Although there were some popular 'cures' for ailments - such as Ward's "Pill and Drop", Dr. John Arbuthnot's diet of "asses milk", Dr. Thomas Dover's "Mercury Powders", and Dr. Robert James's "Fever Powders" effective treatment for the problems facing the country in 1741 was effectively nonexistent ${ }^{14}$. Since the medical establishment was far from institutionalized at this point, Berkeley justified his actions by claiming, "if physicians think they have a right to treat of religious matters, I think I have an equal right to treat of medicine ${ }^{15 "}$. This was the immediate context in which Berkeley began his experiments with tar-water, seeking to alleviate the distress of his neighbors.

\section{Tar-Water : The Panacea and its Critics}

7 Berkeley's letters to his friend Thomas Prior indicate that he first began experimenting with tar-water as a cure for the epidemics afflicting his neighbors in the fall of 1741, but it was only after the danger had passed that he translated his experiences to writing ${ }^{16}$. First published in Dublin, Siris: A Chain of Philosophical Reflexions and Inquiries concerning the Virtues of Tar Water (1744), quickly became a best-seller and passed through six editions before the end of the year ${ }^{17}$. Berkeley's rambling text began with concrete instructions for the preparation of tar-water and a series of case studies of its success in treating a wide array of ailments. Following this initial foray into medicine, Siris meanders from botany to chemistry to metaphysics, before ending with a discussion concerning the nature of God. This structure is in part alluded to by the title itself, since "siris" is a variation of the Greek word for chain, but as Berkeley later noted, this word was also used by the ancient Egyptians to refer to the Nile. In this sense, he suggested "the virtue of tarwater, flowing like the Nile from a secret and occult source, brancheth into innumerable channels, conveying health and relief wherever it is applied ${ }^{18}$. . Here Berkeley pointed out two issues of importance for understanding his goals. First, he suggested that tar-water, like the Nile, could provide a healing function for those who imbibed it. Secondly, his claim that it originated in a "secret and occult source" pointed toward his view of divinity and the notion of sociability that he believed connected all of humanity.

Turning to the first of these issues, the practical side of Siris, Berkeley harbored great hopes for its ability to improve the daily lives of those who drank it. Berkeley began Siris with his own recipe for tar-water and then discussed the types of conditions that he treated with success. In doing so, Berkeley suggested that tar-water could ease nearly every physical problem imaginable, although initially he eschewed using the word "panacea" and tempered his conclusions by repeatedly reminding his readers that his observations were based upon his own personal experiences ${ }^{19}$. For instance, he noted that in 1741, "twenty-five fevers in my own family [were] cured by this medicinal water, drunk copiously ${ }^{20 "}$. His enthusiasm for the potential of tar-water was also evident in his First Letter to Thomas Prior (1744), where he declared "I freely own that I suspect Tar-water is a Panacea [...] [but] that by a Panacea is not meant a Medicine which cures all Individuals, (this consists not with Mortality) but a Medicine that cures or relieves all the different 
Species of Distempers ${ }^{21}$ ". Not only could tar-water cure and prevent natural illnesses, but it could "withstand that execrable Plague of distilled Spirits [...] which Pest of human Kind is, I am told, gaining ground in this Country, already too thin of Inhabitants ${ }^{22}$ ". As described by Berkeley, cheap and plentiful tar-water could safeguard the Irish population and effectively usher in a medical utopia, populated with healthy and productive citizens ${ }^{23}$.

Just as his Bermuda plan had captured the public's imagination, so too did the potential of tar-water. In June 1744 William Duncombe wrote to Archbishop Herring that "It is impossible to write a letter now without tincturing the ink with tar-water ${ }^{24 "}$. In a similar manner, Horace Walpole observed in May 1744 that "we are now mad about tar-water25". By the end of the year, the Tar-Water Warehouse opened in St. James's Street and published excerpts from Siris, along with testimonials as to its usefulness ${ }^{26}$. The virtues of tar-water even inspired poets, such as the author of Tar Water, A Ballad, who implored his audience to laud Berkeley's praises, since he had taken the "sting" from death ${ }^{27}$. Its influence even extended into the netherworld, as a popular tract, Siris in the Shades, purported to relay a conversation over the merits of tar-water in the afterlife ${ }^{28}$.

While the general public rallied behind Berkeley's cure, the medical establishment remained skeptical. Some of these critiqued Berkeley's command of chemistry and modern medical practices, claiming that his efforts were misguided at best and potentially harmful at worst. Leading the attack from the medical establishment was Dr. Thomas Reeve, later President of the Royal College of Physicians, who argued that Siris was riddled with scientific errors. Alluding to Berkeley's earlier philosophic work, Reeve pointed out the irony of "an attempt to talk Men out of their Reason" being lodged by "that Author who had first tried to persuade them out of their Senses ${ }^{29}$ ". Reeve not only charged that Berkeley's "infidelity in our Art is too apparent", but claimed that he knew "very little of the Art [he had] undertaken to disprove ${ }^{30}$ ". Reeve then outlined a series of errors in Siris concerning chemical analyses, concluding that Berkeley had only settled on tar-water due to the fact that it was cheap and easily obtained. Following this logic, Reeve chided Berkeley from failing to acknowledge "mere Water to be more medicinal than TarWater", since it was even more readily available ${ }^{31}$. Still, while Reeve's attack on Berkeley's medical credentials was powerful, for the most part it refrained from ad hominem attacks and relied upon scientific grounds; other critics of Siris were not quite as civil.

James Jurin, Secretary of the Royal Society and later President of the Royal College of Physicians, was a prominent advocate of inoculation techniques and launched one of the more telling assaults on Siris ${ }^{32}$. Questioning Berkeley's allegiance to modern medicine, Jurin feared that Berkeley's plan would "bring again the whole Knowledge of Medicine to its Primitive Darkness to specific Remedies, and occult Qualities ${ }^{33}$ ". In his Letter, Jurin argued that Berkeley misunderstood contemporary medicine, resulting in a farrago of theories without scientific basis. This relatively sober analysis was accompanied by a snide allusion to Pope's famous verse, claiming "the Author has serv'd his Medicine just as Pope serv'd him, by giving it every Virtue under Heaven, he has made all the World conclude it never had any ${ }^{34}$ ". In the end, he announced that "as Bishop of Cloyne, I honour and respect [you], but as a Physician, I despise and pity You ${ }^{35 "}$.

12 While Jurin's judgment was harsh, at least it was premised upon the scientific merits of Siris, unlike the tactics used by the author of Anti-Siris. This pamphlet openly ridiculed tar-water by comparing it to an earlier panacea : red cow urine ${ }^{36}$. Channeling the spirit of Swift, this tract outlined how potent red cow urine could only be collected "one or two 
Months in the Year, and but to a very early Hour in the Morning". Despite its origins, red cow urine commonly led to the "Breach of the public Peace [...] which happen'd every Morning in the Cow Houses about this great Metropolis, when Footmen, Chairmen, and other trusty Messengers from the Ladies broke on another's Heads to be first serv'd with the first plenteous Bounty of the Animal ${ }^{37 "}$. While Anti-Siris questioned the medical qualities of Berkeley's panacea, it also incorporated a political attack. According to AntiSiris, Berkeley's Siris was not meant to be a scientific tract at all, but rather served as a stalking horse for religious reformation. This pamphlet described Siris as a "Medley of Politics and Metaphysics" designed to further Berkeley's "religious and political scheme". It suggested that if tar-water were to prove successful, "the Call for his Commodity here must raise the Price in Norway, which would not only endear our Prince and nation to the Danes, but will enable their King to help us against France without a Subsidy ${ }^{38}$ ". Religiously, Anti-Siris claimed that Berkeley's true aim in publishing this text was to "attack Deism", with the ultimate goal of reforming "church and state ${ }^{39 "}$. According to this reading, Berkeley's concerns for universal health were a mask for his goal of strengthening religious orthodoxy and state power.

In part, these accusations concerning Berkeley's true motives may have been due to his Irish background, a fact that filtered into other responses to Siris with less vitriol. In these cases, Berkeley's Irish heritage and post were not necessarily a cause for alarm, but did raise questions concerning the viability of this cure across the Irish Sea. In his defense of Siris, Philanthropos admitted that Berkeley may have overstated his case, but found some value in tar-water. In part, this stemmed from the nature of Berkeley's flock, on the grounds that "we must make great Allowances for the Patients my Lord prescribe to, viz. upon poor People in Ireland [...] whose Constitutions are in some measure emaciated by a perpetual Revolution of vernal and autumnal Agues, intermitting and other cronic Disorders ${ }^{40}$ ". Risorius questioned the effectiveness of tar-water as a universal panacea and mounted a similarly lukewarm defense. After noting some general problems with Berkeley's analysis, Risorius suggested that tar-water "may be better adapted to the Climate of Ireland, than to English Constitutions; in which Case, the prudent Part would be, to leave it entirely to the Irish ${ }^{41}$ ". In each of these cases, tar-water was dismissed as a panacea, but was seen to have some (limited) use in Ireland where medical care was scarce, thus echoing the argument that Berkeley himself made concerning the paucity of doctors in Cloyne.

In the first section of Siris, Berkeley proposed a solution to one of the foremost problems facing Ireland: the lack of adequate medical care beyond the areas serviced by Dublin. While this effort elicited a number of critiques, the crisis to which he was responding was legitimate and reaching a critical point. In terms of Berkeley's goal of improving Ireland, the notion of a panacea played a crucial role. Not only could tar-water improve the wellbeing of the Irish population, but by providing a healthy workforce the nation as a whole could move forward economically as well. In the second part of Siris Berkeley outlined the metaphysical basis for tar-water's effectiveness, drawing upon Stoic notions of cosmology to support his earlier contention that there was a fundamental sense of sociability among all humans. This universal bond could unite and elevate the nation across sectarian bounds just as the power of tar-water could improve the physical bodies of its population. 


\section{The Stoic Tradition and Berkeley's Siris}

15 Although the first half of Siris was devoted to explicating the benefits of tar-water, Berkeley also provided a series of digressions, or "chain of reflexions", addressing why this liquid was so powerful. In the course of doing so, Berkeley raised a number of philosophical issues that have made this text particularly hard to categorize. As a result, commentators on this text have often tried to locate Siris within the context of Berkeley's career, in order to determine whether it was a new departure for him or a continuation of an earlier project. Berkeley's first biographer, A. A. Luce, suggests that while Siris built upon Berkeley's earlier philosophic system, it was a weak effort that "never should have seen the light of day as such" ${ }^{42}$. Focusing on notions of particles within Siris, Gabriel Moked claims that this text marked a "radical change of mind" regarding the idea of "corpuscularian philosophy ${ }^{43}$ ". Marina Benjamin argues that Siris was the final salvo in Berkeley's long-running attack on deists and freethinkers that sought to "bring wandering souls back to true religion ${ }^{4{ }^{\prime \prime}}$. David Berman also emphasizes the religious nature of Siris and explains the text as an example of Berkeley's "medical idealism", since "tar-water is the closest natural thing to drinkable God"4". A few scholars have taken a different route, choosing to place Siris within "archaic" traditions of the "Great Chain of Being" with roots in Platonism and alchemy ${ }^{46}$. According to this reading, the theory of the Great Chain of Being made it "ontologically possible" for tar-water to be effective ${ }^{47}$.

While these explanations provide important insights into how Berkeley understood tarwater to function, in terms of the larger Irish context a more useful suggestion comes from Timo Airaksinen, who argues that Siris should be seen as imbibing heavily from the Stoic tradition of social thought. According to Airaksinen, Berkeley accepted the Stoic notion that the world "is an organic unity", modeled on the Great Chain of Being and possessing a fundamental sense of harmony ${ }^{48}$. In this case, the chain is constructed in the physical world along a continuum, running from tar to God, with tar itself acting as the "condensation of light" or "an embodiment of the divine life ${ }^{49}$ ". Since tar-water was the distillation of the "divine fire", it could bring beneficial effects to all physical bodies with which it came into contact.

In terms of living beings and consciousness, Berkeley also used this notion of a chain to claim that all the parts of the world, "however distant each from other, are nevertheless related and connected by one common nature [...] a chain or scale of beings rising by gentle uninterrupted gradations from the lowest to the highest, each nature being informed and perfected by the participation of the higher ${ }^{50}$ ". While Airaksinen is right to point out that this ancient tradition indicated the potential for perfectibility among all beings, in terms of Berkeley's understanding of Irish society a more fruitful avenue of approach is to see Siris as part of an important strand of Stoic thought circumscribed by the notion of oikeiosis ${ }^{51}$.

The Greek word oikeiosis may be translated in a variety of ways, but generally denotes an important relationship on par with "endearment" and associated with the development of ever-widening social networks ${ }^{52}$. According to Cicero, "nature, by the power of reason, unites one man to another for the fellowship both of common speech and of life ${ }^{53}$ ". Typically this bond passed outward through a series of concentric circles to include family, friends, states, and eventually (in its full cosmopolitan form) humanity itself ${ }^{54}$. The ultimate source of this movement was self-preservation, but reason allowed humans 
to recognize the value of associating with others ${ }^{55}$. Additionally, a key part of this outward movement stressed the moral injunction for humans to improve themselves and display benevolence towards others. According to the Stoics, this connection between humans was governed and inspired by a divine will that provided harmony within the universe ${ }^{56}$. Cicero stressed that this sense of fellowship needed to be accompanied by the virtue of learning, yoking the elevation of the individual mind upward with a sense of sociability ${ }^{57}$. Thus, as humans developed, they were expected to evolve from purely physical concerns "into thinking animals, who prefer mental to bodily well-being 58 ". In the end, he concluded there were "degrees of duties within social life itself", culminating in "that vast fellowship of the human race" on par with an early form of cosmopolitanism ${ }^{59}$. In this manner, Stoics linked sociability with divine oversight and the need to elevate humanity. By the eighteenth century, this "out-and-up" movement was associated with a Christianized form of Stoicism and provides a useful conceptual tool for describing the mechanism supporting Berkeley's system in Siris and harkens back to his earlier works ${ }^{60}$.

In Siris, Berkeley explores this notion of oikeiosis in two important ways. The first of these is alluded to by the title and structure of the work, since the flowing nature of the former is reflected by the organization of the latter. According to the Stoics, humans are first drawn to their immediate surroundings in the material world and it requires the exercise of reason to elevate the soul and allow for an appreciation of higher, more abstract, forms of the good. Berkeley embedded a sense of this process of gradual enlightenment within the structure of Siris. Berkeley's text begins with a close examination of the physical benefits of tar-water, grounding his analysis in the material sciences of botany and chemistry. This focus gradually shifts towards a metaphysical exploration of the nature of reality and the divine, just as the Stoics suggested that the process of oikeiosis led humans to enlightenment. As a result, the "reader only interested in the latest cure" is guided along a path of "speculative ascent" to "consider divine subjects without his being aware of the transition" ${ }^{61 "}$.

20 In addition to this structural evocation of oikeiosis, Berkeley also addresses this issue more formally in his explanation of the ties uniting disparate individuals, suggesting that tarwater was not only a panacea for the body, but a potent symbol of human improvement. At the core of Berkeley's analysis was an appreciation for Stoic cosmology. In Siris, Berkeley contended that there is a "hidden force that unites, adjusts, and causeth all things to hang together, and move in harmony [...] this principle of union is no blind principle, but acts with intellect [...] Intellect enlightens, Love connects, and the sovereign good attracts all things ${ }^{62}$. This appeal to a divine source of harmony, echoing the Stoic notion of a pneuma shaping the universe, provided the basis for Berkeley's explanation of social interaction ${ }^{63}$. After outlining classical notions of fate, Berkeley appealed to the Stoic idea of the "world as an animal" when he suggested that "the mutual relation, connection, motion, and sympathy of the parts of this world, that they seem as it were animated and held together by one soul : and such is their harmony, order, and regular course, as shweweth the soul to be governed and directed by a mind ${ }^{64 "}$. In this sense, Berkeley's adoption of the Stoic notion of universal harmony and the attraction between individuals provided the first step in the process of oikeiosis - the outward bond of sociability between humans - which was coupled with the upward movement toward intellectual improvement.

21 After tracing the origins and nature of harmony within the natural world, Berkeley turned his analysis to the mental world. He contended that : 
from the outward form of gross masses which occupy the vulgar, a curious inquirer proceeds to examine the inward structure and minute parts, and from observing the motions in nature, to discover the laws of those motions [...] But, if proceeding still in his analysis and inquiry, he ascends from the sensible into the intellectual world, and beholds things in a new light and a new order ${ }^{65}$.

For Berkeley, human nature and the harmony of the universe engendered an obligation for individuals to expand their knowledge and to elevate their minds upward toward a more refined understanding of their telos. Berkeley carefully explained the various types of knowledge, noting how each step in the process leads to a finer appreciation of the divine. He argued that "by experiments of sense we become acquainted with the lower faculties of the soul; and from them, whether by a gradual evolution or ascent, we arrive at the highest [...] in this scale, each lower faculty is a step that leads to one above it. And the uppermost naturally leads to the Deity ${ }^{60 "}$. In making this link between the lower and higher faculties, Berkeley echoed the widespread notion of a "great chain of being". At the core of this idea was a belief that the universe was constructed along the principles of plentitude, continuity, and gradation, which resulted in a smooth vertical spectrum of various "intelligences" (or "species") ranging from the lowest worm to God. Applied to human social systems, this metaphor was typically used to support an "ethics of prudent mediocrity [...] man's duty was to keep his [social] place, and not to seek to transcend it ${ }^{67}$ ". Typically, political appeals to the idea of the "great chain of being" were grounded in an attempt to justify the political status quo. One was born into a position on the social ladder through the will of God and should therefore remain on the same rung for life. By using the metaphor of a chain to highlight the horizontal connections between individuals and to stress the principle of attraction (rather than hierarchy), Berkeley effectively tilted the great chain of being on its side. For him, as for the Stoic advocates of oikeiosis, the primary value of this image was to show the relationship between humans, rather than between species or orders. In this case, Berkeley contended that an appreciation for the ties between individuals (the outward movement) and toward the divine (the upward movement) were essential for political leaders. He claimed, "he who hath not much meditated upon God, the Humane mind, and the Summum bonum, may possibly make an able earthworm, but will most indubitably make a sorry patriot and a sorry statesman ${ }^{68}$. In the Irish case, this cosmopolitan vision of human sociability suggested that sectarian lines were human constructs that could be cast aside as the overall level of consciousness within society was raised. Thus, tar-water was the physical manifestation of Berkeley's larger metaphysical belief in the need to improve the physical and spiritual conditions of the nation.

\section{Conclusion}

Taken as a whole, Berkeley's Siris presented two related ideas for the improvement of Irish society during the 1740s. The first of these addressed the physical world through the medicinal effects of tar-water and aimed to ensure the health and well-being of a people sorely lacking proper care. By providing a cheap and easy manner to prevent illness in a society that faced frequent epidemics, Berkeley's Siris may be seen as an effort to alleviate wide-spread suffering across sectarian lines. At the same time, the metaphysical notion of sociability embodied in the Stoic idea of oikeiosis provided a cosmopolitan justification for casting aside religious differences and recognizing the innate humanity of all inhabitants of Ireland. By calling upon political leaders to jettison sectarian divisions in favor of a 
universal definition of humanity and yoking this with the need to elevate their consciousness, Berkeley provided a model for the amelioration of the problems facing Ireland. Thus, in the end, Berkeley sought to care for both the physical and spiritual sides of the Irish body politic, with the hope of laying a foundation for social improvement and uplift.

\section{NOTES}

1. Emmanuel Kant, Critique of Pure Reason, 1787, Norman Kemp Smith (trans.), New York, St. Martin's Press, 1929, p. 89.

2. Ian Tipton, Berkeley: The Philosophy of Immaterialism, 1974, Bristol, Thoemmes Press, 1994, p. 4.

3. Stephen Clark, "Introduction", Money, Obedience, and Affection: Essays on Berkeley's Moral and Political Thought, Stephen Clark (ed.), New York, Garland Publishing, 1989, p. VII.

4. Alexander Pope, "Epilogue to the Satires. Dialogue II", Imitations of Horace with An Epistle to Dr. Arbuthnot and The Epilogue to the Satires, John Butt (ed.), London, Methuen, 1939, p. 317.

5. A. A. Luce, The Life of George Berkeley, Bishop of Cloyne, London, Thomas Nelson, 1949, p. 192.

6. W. R. C., Tour through Ireland in Several Entertaining Letters, Dublin, 1746, v. 1, p. 63 and Carole Fabricant, "George Berkeley the Islander", The Global Eighteenth Century, Felicity Nussbaum (ed.), Baltimore, Johns Hopkins, 2003, p. 275.

7. Anonymous, The Distress'd State of Ireland Considered; More Particularly with Respect to the North, in a Letter to a Friend, Dublin, 1741, p. 4.

8. Luce, Life of Berkeley, p. 199.

9. Anonymous, A Proposal for Lessening the Excessive Price of Bread Corn in Ireland, Dublin, R. Reilly, 1741, p. 4.

10. Fabricant, "Berkeley the Islander", p. 275 and George Berkeley to Thomas Prior [8 February 1740/41], The Works of George Berkeley, Bishop of Cloyne, A. A. Luce and T. E. Jessop (eds.), Edinburgh, Thomas Nelson, 1948-57, v. 8, p. 248.

11. Berkeley to Prior [19 May 1741], in Works, v. 8, p. 251-252.

12. Anonymous, The Groans of Ireland in a Letter to a Member of Parliament, Dublin, George Faulkner, 1741, p. 3.

13. Luce, Life of Berkeley, p. 198.

14. Marina Benjamin, “Medicine, Morality and the Politics of Berkeley's Tar-Water”, The Medical Enlightenment of the Eighteenth Century, Andrew Cunningham and Roger French (eds.), Cambridge, Cambridge University Press, 1990, pp. 165-93; Marjorie Nicolson, “Joshua War's 'Pill and Drop', and Men of Letters”, Journal of the History of Ideas, 29, 1968, pp. 177-96 and Roy Porter, "Lay Medical Knowledge in the Eighteenth Century: The Evidence of the Gentleman's Magazine”, Medical History, 29, 1985, pp. 138-68. 
15. Berkeley, First Letter to Thomas Prior, in Works v. 5, p. 173.

16. Ian Tipton, "Two Questions on Bishop Berkeley's Panacea", Journal of the History of Ideas, 30, 1969, p. 217.

17. E. J. Furlong and W. V. Denard, “The Dating of the Editions of Berkeley's Siris and of his first Letter to Thomas Prior", Hermathena, 86, 1955, p. 66-76.

18. Berkeley, Second Letter to Thomas Prior, in Works, v. 5, p. 185.

19. Peter Walmsley, The Rhetoric of Berkeley's Philosophy, Cambridge, Cambridge University Press, 1990, p. 150.

20. George Berkeley, Siris: A Chain of Philosophical Reflexions and Inquiries concerning the Virtues of Tar-Water and divers other Subjects connected together and arising one from another, in Works, v. 5, p. 56.

21. Berkeley, First Letter, in Works, v. 5, p. 175.

22. Ibid., p. 180. For information on Siris and alcohol, see David Berman, "Berkeley's Siris and the "Whisky Patriots"', Eighteenth Century Ireland, 1, 1986, p. 200-203.

23. Both Fabricant and Bradatan note the utopian element of Siris. Fabricant, "Berkeley the Islander", p. 277-278 and Costica Bradatan, "One is All, and All is One: The Great Chain of Being in Berkeley's Siris", Ordering the World in the Eighteenth Century, Frank O'Gorman and Diana Donald (eds.), New York, Palgrave Macmillan, 2006, p. 63-82.

24. Luce, Life of Berkeley, p. 201.

25. Horace Walpole's Correspondence with Sir Horace Mann, W. S. Lewis (ed.), New Haven, 1955, v. 2, p. 451

26. Anonymous, The Medicinal Virtues of Tar Water Fully Explained, Dublin, 1744.

27. Anonymous, Tar Water, A Ballad, Inscribed to the Right Honourable Philip Earl of Chesterfield , London, W. Webb, 1747, p. 4.

28. Anonymous, Siris in the Shades: A Dialogue concerning Tar Water; Between Mr. Benjamin Smith, lately deceased, Dr. Hancock, and Dr. Garth, at their meeting upon the banks of the River Styx, London, C. B., 1744.

29. Thomas Reeve, A Cure for the Epidemical Madness of Drinking Tar Water, Lately imported from IRELAND, London, John and Paul Knapton, 1744, p. 2.

30. Ibid., p. 3-4.

31. Ibid., p. 59.

32. Marjorie Nicolson and G. S. Rousseau, "Bishop Berkeley and Tar-Water", The Augustan Milieu, Henry Miller (ed.), Oxford, Clarendon Press, 1970, p. 118.

33. James Jurin, A Letter to the Right Reverend the Bishop of Cloyne, Occasion'd by His Lordship's Treatise on the Virtues of Tar-Water, London, Jacob Robinson, 1744, p. 8.

34. Ibid., p. 11.

35. Ibid., p. 39.

36. Anonymous, Anti-Siris: Or, English Wisdom Exemplify'd by various Examples, but Particularly the present general Demand for Tar Water, London, M. Cooper, 1744, p. 34.

37. Ibid., p. 35-36.

38. Ibid., p. 50.

39. Ibid., p. 56 and p. 57. 
40. Philanthropos, The Bishop of Cloyne Defended; or Tar-Water Proved Useful, London, J. Rivington, 1744, p. 18.

41. Risorius, Remarks on the Bishop of Cloyne's Book, Entitled Siris, London, J. Roberts, 1744, p. 7.

42. A. A. Luce, "Berkeley's Search for Truth", Hermathena, 81, 1951, p. 22.

43. Gabriel Moked, Particles and Ideas: Bishop Berkeley's Corpuscularian Philosophy, Oxford, Clarendon Press, 1988, p. 1.

44. Benjamin, "Politics of Berkeley's Tar-Water", p. 169.

45. David Berman, George Berkeley: Idealism and the Man, Oxford, Clarendon Press, 1994, p. 173.

46. A. D. Richie, “George Berkeley's Siris: The Philosophy of the Great Chain of Being and the Alchemical Theory", Proceedings of the British Academy, 40, 1954, p. 41-55.

47. Bradatan, "Berkeley's Siris", p. 72.

48. Timo Airakinen, "The Chain and the Animal: Idealism in Berkeley's Siris", Eriugena, Berkeley, and the Idealist Tradition, Stephen Gersh and Dermot Moran (eds.), Notre Dame, University Press of Notre Dame, 2006, p. 226-227.

49. Ibid., p. 236.

50. Berkeley, Siris, in Works, v. 5, p. 129.

51. For an analysis of the influence of Stoicism on Berkelely's philosophical thought, see Stephen Daniel, "Berkeley's Stoic Notion of Spiritual Substance", New Interpretations of Berkeley's Thought, Stephen Daniel (ed.), Amherst, Humanity Books, 2008.

52. S. G. Pembroke, "Oikeiosis", Problems in Stoicism, A. A. Long (ed.), London, Athlone Press, 1971, pp. 114-16; Gretchen Reydams-Schils, The Roman Stoics: Self, Responsibility, and Affection, Chicago, University of Chicago Press, 2005, pp. 55-59; Nicholas White, "The Basis of Stoic Ethics", Harvard Studies in Classical Philology, 83, 1979, p. 145; and Troels EngbergPedersen, The Stoic Theory of Oikeiosis, Aarhus University Press, 1990.

53. Cicero, On Duties, M. T. Griffin (ed.), Cambridge, Cambridge University Press, 1991, p. 6.

54. Pembroke, "Oikeiosis", p. 125-26 and Cicero, Duties, p. 22-23.

55. Ibid., p. 6.

56. See Reydams-Schils, Roman Stoics, p. 57.

57. Cicero, Duties, p. 61. Also see Pembroke, “Oikeiosis", p. 129.

58. A. A. Long, Stoic Studies, Berkeley, University of California Press, 1996, p. 262.

59. Cicero, Duties, p. 22-23. Also, see Martha Nussbaum, "Kant and Stoic Cosmopolitanism", Journal of Political Philosophy, 5, 1997, pp. 5-7.

60. Laurence Dickey, "Doux-commerce and humanitarian values: free trade, sociability, and universal benevolence in eighteenth-century thinking", Grotiana, 22, 2004, pp. 284-85.

61. Walmsley, Berkeley's Philosophy, p. 144-145.

62. Berkeley, Siris, in Works, v. 5, p. 122.

63. B. J. T. Dobbs, "Stoic and Epicurean doctrines in Newton", Atoms, pneuma, and Tranquility: Epicurean and Stoic Themes in European Thought, Margaret Osler (ed.), Cambridge, Cambridge University Press, 1991, p. 224.

64. Berkeley, Siris, in Works, v. 5, p. 128-29.

65. Ibid., p. 137. 
66. Ibid., p. 140.

67. Arthur O. Lovejoy, The Great Chain of Being: A Study of the History of an Idea, New York, Harper, 1936, p. 200.

68. Berkeley, Siris, in Works, v. 5, p. 157-158.

\section{ABSTRACTS}

After being appointed Bishop of Cloyne, the Irish philosopher George Berkeley confronted the harsh conditions facing his charges. In response, Berkeley published his controversial, and oftoverlooked, Siris (1744). This paper examines Berkeley's call for the use of "tar water" as both a preventative medicine and panacea, surveying popular responses to it and showing how it was built upon a Stoic vision of sociability (oikeiosis) aimed at improving the welfare of the nation.

Après avoir été nommé évêque de Cloyne, le philosophe irlandais George Berkeley a dû affronter les difficiles conditions sociales auxquelles sa charge le confrontait. C'est en réponse à celles-ci qu'il a publié son œuvre controversée et souvent sous-estimée, Siris (1744). Cet article examine l'appel de Berkeley à utiliser "l'eau de goudron" comme médicament préventif et universel, étudie la réaction du public de l'époque, et cherche à montrer comment l'approche de Berkeley se fonde une vision stoïcienne de la sociabilité (oikeiosis) ayant pour but d'améliorer le bien-être de la nation.

\section{INDEX}

Mots-clés: Berkeley George, philosophie - stoïciens, intellectuels, science

Keywords: philosophy - stoics, Berkeley George, science, intellectuals

\section{AUTHOR}

\section{SCOTT BREUNINGER}

University of South Dakota, USA 